\title{
Autotrophic growth of anaerobic ammonium-oxidizing micro-organisms in a fluidized bed reactor
}

\author{
Astrid A. van de Graaf, $\nmid$ Peter de Bruijn, Lesley A. Robertson, \\ Mike S. M. Jetten and J. Gijs Kuenen \\ Author for correspondence: Mike S. M. Jetten. Tel: + 31152781193 . Fax : + 31152782355 \\ e-mail: M.Jetten@STM.TUDelft.NI.
}

Kluyver Laboratory for

Biotechnology,

Department of

Microbiology and

Enzymology, Delft

University of Technology,

Julianalaan 67,2628 BC

Delft, The Netherlands

\begin{abstract}
An autotrophic, synthetic medium for the enrichment of anaerobic ammonium-oxidizing (Anammox) micro-organisms was developed. This medium contained ammonium and nitrite, as the only electron donor and electron acceptor, respectively, while carbonate was the only carbon source provided. Preliminary studies showed that the presence of nitrite and the absence of organic electron donors were essential for Anammox activity. The conversion rate of the enrichment culture in a fluidized bed reactor was $3 \mathbf{~ k g}$ $\mathrm{NH}_{4}^{+} \mathbf{m}^{-3} \mathrm{~d}^{-1}$ when fed with $30 \mathrm{mM} \mathrm{NH}_{4}^{+}$. This is equivalent to a specific anaerobic ammonium oxidation rate of $1000-1100 \mathrm{nmol} \mathrm{NH}_{4}^{+} \mathrm{h}^{-1}\left(\mathrm{mg}\right.$ volatile solids) ${ }^{-1}$. The maximum specific oxidation rate obtained was $1500 \mathrm{nmol} \mathrm{NH}_{4}^{+} \mathrm{h}^{-1}$ (mg volatile solids) ${ }^{-1}$. Per mol $\mathrm{NH}_{4}^{+}$oxidized, $0.041 \mathrm{~mol} \mathrm{CO}_{2}$ were incorporated, resulting in a estimated growth rate of $0.001 \mathrm{~h}^{-1}$. The main product of the Anammox reaction is $\mathrm{N}_{2}$, but about $10 \%$ of the $\mathrm{N}$-feed is converted to $\mathrm{NO}_{3}^{-}$. The overall nitrogen balance gave a ratio of $\mathrm{NH}_{4}^{+}$-conversion to $\mathrm{NO}_{2}^{-}$-conversion and $\mathrm{NO}_{3}^{-}$-production of 1:1.31 $\pm 0.06: 0.22 \pm 0.02$. During the conversion of $\mathrm{NH}_{4}^{+}$with $\mathrm{NO}_{2}^{-}$, no other intermediates or end-products such as hydroxylamine, $\mathrm{NO}$ and $\mathrm{N}_{2} \mathrm{O}$ could be detected. Acetylene, phosphate and oxygen were shown to be strong inhibitors of the Anammox activity. The dominant type of micro-organism in the enrichment culture was an irregularly shaped cell with an unusual morphology. During the enrichment for Anammox micro-organisms on synthetic medium, an increase in ether lipids was observed. The colour of the biomass changed from brownish to red, which was accompanied by an increase in the cytochrome content. Cytochrome spectra showed a peak at $470 \mathbf{~ n m}$ gradually increasing in intensity during enrichment.
\end{abstract}

Keywords : ammonium, nitrite, dinitrogen gas, nitrification, denitrification

\section{INTRODUCTION}

Ammonium is a common pollutant which is normally eliminated from waste water by a combination of two processes, nitrification and denitrification. Nitrification is the biological formation of nitrate or nitrite from compounds containing reduced nitrogen with $\mathrm{O}_{2}$ as the terminal electron acceptor. Two separate and distinct

tPresent address: IMPULS Science \& Technology Center, PO Box 421, 1000 AK Amsterdam, The Netherlands.

Abbreviations: Anammox, ANaerobic AMMonium OXidation/-OXidizing; FBR, fluidized bed reactor; RuBPCase, ribulose-1,5-bisphosphate carboxylase; VS, volatile solids. steps are involved in nitrification. First, the oxidation of $\mathrm{NH}_{4}^{+}$to $\mathrm{NO}_{2}^{-}$is carried out by ammonium-oxidizing bacteria such as Nitrosomonas or Nitrosospira (Koops \& Möller, 1992). This is followed by the oxidation of $\mathrm{NO}_{2}^{-}$ to $\mathrm{NO}_{3}^{-}$by nitrite-oxidizing bacteria such as Nitrobacterlike organisms (Abeliovich, 1992). During the subsequent denitrification step, $\mathrm{NO}_{3}^{-}$or $\mathrm{NO}_{2}^{-}$are reduced to $\mathrm{N}_{2}$ by denitrifying bacteria. Denitrification is carried out by a wide spectrum of respiratory bacteria representing many genera and physiological types (Kuenen \& Robertson, 1994; Zumft, 1992).

Recently, a novel anaerobic process in which ammonium was used as electron donor for denitrification was discovered in a laboratory-scale fluidized bed reactor 
(FBR) (Mulder et al., 1995). It was demonstrated that in this ANaerobic AMMonium OXidation/-OXidizing (Anammox) process, nitrate was used as an electron acceptor. Redox balance calculations showed the following stoichiometry:

$$
\begin{aligned}
5 \mathrm{NH}_{4}^{+}+3 \mathrm{NO}_{3}^{-} \rightarrow & 4 \mathrm{~N}_{2}+9 \mathrm{H}_{2} \mathrm{O}+2 \mathrm{H}^{+} \\
\Delta G^{0^{\prime}}=-297 \mathrm{~kJ}(\mathrm{~mol} \mathrm{NH} & \left.\mathrm{NH}_{4}^{+}\right)^{-1}
\end{aligned}
$$

During further examination of this new process, which is catalysed by an as yet unidentified mixed microbial population, indications were obtained that nitrite could also serve as a suitable electron acceptor for the Anammox process (van de Graaf et al., 1995).

$$
\begin{aligned}
& \mathrm{NH}_{4}^{+}+\mathrm{NO}_{2}^{-} \rightarrow \mathrm{N}_{2}+2 \mathrm{H}_{2} \mathrm{O} \\
& \left.\Delta G^{0 \prime}=-358 \mathrm{~kJ}(\operatorname{mol~NH})^{+}\right)^{-1}
\end{aligned}
$$

To obtain a more fundamental understanding of this new process, we developed a synthetic inorganic mineral medium for the enrichment of the micro-organisms capable of Anammox in an FBR. This paper reports on the characteristics and properties of this enrichment culture.

\section{METHODS}

Origin of biomass. Sludge from a 271 denitrifying FBR in which the Anammox process occurred was used as the source for biomass (Mulder et al., 1995). When used in batch experiments, the sludge was homogenized by passing it several times through a $60 \mathrm{ml}$ syringe. For continuous experiments, a small denitrifying FBR $(2.5 \mathrm{l})$ was directly fed with the effluent from a methanogenic reactor. Details of the system are described by Mulder et al. (1995).

Mineral medium. For the start-up of the small FBR, an anaerobic synthetic medium was used. This medium contained (per 1 demineralized water): $\left(\mathrm{NH}_{4}\right)_{2} \mathrm{SO}_{4}, 330 \mathrm{mg}(5 \mathrm{mM})$; $\mathrm{NaNO}_{2}, 345 \mathrm{mg}(5 \mathrm{mM}) ; \mathrm{KHCO}_{3}, 500 \mathrm{mg} ; \mathrm{KH}_{2} \mathrm{PO}_{4}, 27 \cdot 2 \mathrm{mg}$; $\mathrm{MgSO}_{4} \cdot 7 \mathrm{H}_{2} \mathrm{O}, 300 \mathrm{mg} ; \mathrm{CaCl}_{2} \cdot 2 \mathrm{H}_{2} \mathrm{O}, 180 \mathrm{mg}$, and $1 \mathrm{ml}$ trace element solutions I and II. Trace element solution I contained (per 1 demineralized water): EDTA, $5 \mathrm{~g} ; \mathrm{FeSO}_{4}, 5 \mathrm{~g}$; and trace element solution II contained (per l demineralized water): EDTA, $15 \mathrm{~g} ; \mathrm{ZnSO}_{4} .7 \mathrm{H}_{2} \mathrm{O}, 0.43 \mathrm{~g} ; \mathrm{CoCl}_{2} .6 \mathrm{H}_{2} \mathrm{O}, 0.24 \mathrm{~g}$; $\mathrm{MnCl}_{2} .4 \mathrm{H}_{2} \mathrm{O}, 0.99 \mathrm{~g} ; \mathrm{CuSO}_{4} .5 \mathrm{H}_{2} \mathrm{O}, 0.25 \mathrm{~g} ; \mathrm{NaMoO}_{4} .2 \mathrm{H}_{2} \mathrm{O}$, $0.22 \mathrm{~g} ; \mathrm{NiCl}_{2}$. $6 \mathrm{H}_{2} \mathrm{O}, 0.19 \mathrm{~g} ; \mathrm{NaSeO}_{4} .10 \mathrm{H}_{2} \mathrm{O}, 0.21 \mathrm{~g} ; \mathrm{H}_{3} \mathrm{BO}_{4}$, $0.014 \mathrm{~g}$. The mineral medium was autoclaved at $120^{\circ} \mathrm{C}$. Solutions of trace elements, $\mathrm{CaCl}_{2}$ and $\mathrm{MgSO}_{4}$ were sterilized separately at $120^{\circ} \mathrm{C}$ and added aseptically to the autoclaved medium. After cooling, the medium was flushed with argon for at least $30 \mathrm{~min}$ to achieve anaerobic conditions. After the startup, ammonium and nitrite concentrations were increased by steps of $5 \mathrm{mM}$.

Operation and continuous experiments with the FBR run with waste water. The glass FBR of 2.51 was operated at $36{ }^{\circ} \mathrm{C}$ and $\mathrm{pH} 7$. Batch experiments with the reactor had confirmed that these were the preferred temperature and $\mathrm{pH}$. The $\mathrm{pH}$ was adjusted with $0.5 \mathrm{M} \mathrm{H}_{2} \mathrm{SO}_{4}$ or $0.5 \mathrm{M} \mathrm{NaOH}$. Anoxic liquid from the top of the reactor was recirculated to boost the flow to approximately $47 \mathrm{l} \mathrm{h}^{-1}$ in order to keep the bed fluidized at a superficial liquid velocity of $24 \mathrm{~m} \mathrm{~h}^{-1}$. The hydraulic retention time was $4 \cdot 2 \mathrm{~h}$. The influent (see below) of the reactor was supplied at a rate of $600 \mathrm{ml} \mathrm{h}^{-1}$. A nitrate solution $(60 \mathrm{~g}$ $\mathrm{NaNO}_{3} \mathrm{l}^{-1}$ ) was supplied at a rate of about $13 \mathrm{ml} \mathrm{h}^{-1}$. Sand particles (diameter $0.3-0.6 \mathrm{~mm}$ ) were the carrier material of the fluidized bed on which bacteria grew as a biolayer. The reactor was inoculated with a large amount of sand covered with denitrifying and Anammox biofilms (400 ml), originating from the $27 \mathrm{l}$ installation (Mulder et al., 1995). This resulted in fast start-up of the experiments.

Samples of the influent and effluent of the reactor were taken once or twice a day and analysed for ammonium, nitrate, nitrite, sulfide, sulfate and sometimes for dissolved organic carbon. Gas production was monitored continuously. All tubing and connectors were of butyl rubber, norprene or polyvinylchloride to limit oxygen diffusion. For the same reason, the settler at the top of the reactor was flushed with argon.

Pulse experiments were conducted to measure the effect of different electron donors, electron acceptors and other medium components on the Anammox activity. A component was supplied to the reactor for $1 \mathrm{~d}$ and the effect was measured by following the effluent ammonium concentration. At least 1 week was allowed for the biomass to regain its original activity. During these experiments, the FBR was run continuously, or on a few occasions, in an intermittent feeding mode. For these experiments, ammonium removal was controlled at $50 \%$ of the influent concentration by removal or addition of biomass, allowing the determination of positive or negative effects.

Operation and continuous experiments with the FBR run with synthetic medium. After the pulse experiments were finished, the influent of the FBR was changed to synthetic medium. The temperature was decreased to $30^{\circ} \mathrm{C}$. For practical reasons, concentrated synthetic medium was supplied at a rate of $200 \mathrm{ml} \mathrm{h}^{-1}$ and diluted with tap water at a rate of $400 \mathrm{ml} \mathrm{h}^{-1}$. Both the medium and the tap water were continuously flushed with argon to maintain anaerobic conditions.

The experiments with synthetic medium were started in batch mode using the original waste water, to ensure that the sludge was actively oxidizing ammonium anaerobically. Continuous feeding of the synthetic medium $\left(5 \mathrm{mM} \mathrm{NH}_{4}^{+}, 5 \mathrm{mM} \mathrm{NO}_{2}^{-}\right)$to the reactor was started after the ammonium concentration reached zero. The influent concentration was raised by steps of $5 \mathrm{mM}$ over a period of 3 months until $30 \mathrm{mM}$ was reached.

Anaerobic batch culture experiments with waste water or synthetic medium. Anaerobic batch experiments with waste water were conducted in $500 \mathrm{ml}$ serum bottles under static anaerobic incubation in the dark at $37^{\circ} \mathrm{C}$, as described previously by van de Graaf et al. (1995). For every type of addition, an independent batch culture was used. Separately, a control batch with ammonium and nitrate was monitored over the whole course of the experiment.

Anaerobic batch experiments with synthetic medium were conducted in $30 \mathrm{ml}$ serum bottles with static incubation in the dark at $30^{\circ} \mathrm{C}$. Each bottle contained $24 \mathrm{ml}$ mineral medium ( $\mathrm{pH} 7$ ) and $1 \mathrm{ml}$ biomass suspension obtained from the enrichment culture grown on synthetic medium.

Ribulose-1,5-bisphosphate carboxylase (RuBPCase) assay. Sludge was harvested from the FBR, separated from the sand particles, and, after centrifugating $(10000 \mathrm{~g}, 10 \mathrm{~min})$, washed with a buffer containing $100 \mathrm{mM}$ Tris $/ \mathrm{HCl}, 20 \mathrm{mM} \mathrm{MgCl}$, $2 \cdot 0 \mathrm{mM} \mathrm{NaHCO}(\mathrm{pH} 8 \cdot 2)$. For preparation of cell-free extracts, the cells were resuspended in the same buffer with $5 \mathrm{mM}$ DTT to a biomass concentration of approximately $30 \mathrm{mg}$ dry weight $\mathrm{ml}^{-1}$ and were disrupted by sonication at $4{ }^{\circ} \mathrm{C}$ in an MSE $150 \mathrm{~W}$ sonifier (eight bursts of $30 \mathrm{~s}$ with intermittent cooling). Intact cells and debris were removed by centrifugating $(20000 \mathrm{~g}$, $20 \mathrm{~min}$ ). RuBPCase was assayed as described by Beudeker $e t$ al. (1980)

${ }^{14} \mathrm{CO}_{2}$-fixation assay. Sludge was harvested from the FBR. After settling, the sludge was rinsed four times with anaerobic 
tap water. The same volume of medium without substrate was added to the biomass. The cells were separated from the sand particles by passing it several times through a $60 \mathrm{ml}$ syringe. Sludge suspension $(1 \mathrm{ml})$ and $9 \mathrm{ml}$ medium containing $2 \mathrm{mM}$ $\mathrm{KHCO}_{3}(\mathrm{pH} 7$ ) was incubated in $25 \mathrm{ml}$ flasks with butyl rubber septa. After flushing the flasks with argon for $10 \mathrm{~min}$, and preincubation at $30^{\circ} \mathrm{C}, 100 \mu{ }^{14} \mathrm{C}$-labelled bicarbonate solution (stock $50 \mathrm{mM} \mathrm{NaH}{ }^{14} \mathrm{CO}_{3}, 31.45 \mathrm{GBq} \mathrm{mol}^{-1}$ ) was introduced. The flasks were incubated in the dark at $30^{\circ} \mathrm{C}$. At predetermined time intervals, $0.5 \mathrm{ml}$ samples (in duplicate) were taken to measure ${ }^{14} \mathrm{CO}_{2}$ incorporation. At the same time, samples for ammonium and nitrite determinations were taken from separately incubated flasks without labelled $\mathrm{CO}_{2}$. The samples for ${ }^{14} \mathrm{CO}_{2}$ measurements were washed three times with $25 \mathrm{mM}$ $\mathrm{KH}_{2} \mathrm{PO}_{4}$ buffer $(\mathrm{pH} 8)$ and transferred to scintillation bottles for counting.

Determination of aerobic nitrifiers. Estimates of ammonium and nitrite-oxidizing populations were made by the most probable number (MPN) method according to Alexander (1982). Six-week incubations were done at 30 and $26^{\circ} \mathrm{C}$ in the dark for ammonium and nitrite oxidizers, respectively. Petri dishes (Sterilin) of $100 \times 100 \mathrm{~mm}$ with 25 square holes filled with $5 \mathrm{ml}$ medium (Schmidt \& Belser, 1982) were used to incubate the MPN dilutions. The result of an MPN test was considered to be positive when either nitrite formation could be detected, or when nitrite had disappeared and nitrate had been formed. Every incubation series was done in duplicate and several times a pure culture of Nitrosomonas europaea LMD 86.25 (culture collection of the Department of Microbiology and Enzymology, Delft, The Netherlands) and Nitrobacter winogradskyi (kindly provided by Drs W. de Boer \& H. J. Laanbroek, Heteren, The Netherlands) were used as controls.

TLC. Cells were harvested from the FBR and, after removal of the sand particles, freeze-dried and stored before use. TLC analysis of whole-cell methanolysates were assayed as described by Ross et al. (1981).

Electron microscopy. Cells were fixed in glutaraldehyde, embedded in Spurr and stained with osmium tetroxide and ruthenium red. Ultra-thin sections were studied in a Philips EM201.

Cytochrome spectra. The spectra were measured with an Aminco DW-2a dual-wavelength spectrophotometer (American Instruments) which was equipped with computer data acquisition (kindly made available by $\operatorname{Dr} \mathrm{A}$. H. Stouthamer of the Free University of Amsterdam). The cell suspensions in $50 \mathrm{mM}$ phosphate buffer were measured at room temperature and at $77 \mathrm{~K}$. The protein content of the suspensions were measured and the spectra were all normalized at $1 \mathrm{mg}$ protein $\mathrm{ml}^{-1}$. The spectrophotometer was equipped with a magnetic stirrer and the cuvettes were closed by a lid fitted to allow continuous flushing of gas and making of additions. The cytochromes were reduced with $60 \mu \mathrm{l}$ dithionite solution $\left(0 \cdot 1 \mathrm{~g} \mathrm{~m}^{-1}\right)$. For $\mathrm{CO}$ spectra, this gas was allowed to react for $15 \mathrm{~min}$ with the cytochromes. To remove the CO ligands, the frozen suspension was exposed to an intense light source for five intervals of $10 \mathrm{~s}$ (Intralux 5000, $185 \mathrm{~W}$ ). All spectra were measured at a reference wavelength of $540 \mathrm{~nm}$. For further handling of the spectral data, the methods and software described by van Wielink et al. (1982) were used.

Analytical procedures. Nitrate, nitrite, ammonium, sulfide and sulfate were determined as previously described (van de Graaf et al., 1995). Hydroxylamine was determined colorimetrically (Frear \& Burell, 1955). Nitrous oxide formation was checked using a GC (Hewlett-Packard model 428) with catharometeric detection. Dry weight was determined by drying the sample at $65^{\circ} \mathrm{C}$ for at least $24 \mathrm{~h}$. The quantity of sand in the dried sample was measured after ashing at $700^{\circ} \mathrm{C}$ for $1 \mathrm{~h}$. The dry weight minus the ashed weight is hereafter termed volatile solids (VSs), Protein for the cytochrome spectra was determined according to Herbert et al. (1971).

Chemicals. Ribulose 1,5-bisphosphate was obtained from Sig$\mathrm{ma}$, and $\left[{ }^{14} \mathrm{C}\right] \mathrm{NaHCO}_{3}\left(2 \cdot 11 \mathrm{TBq} \mathrm{mol}^{-1}\right)$ was from Amersham International. All other chemicals used were reagent grade and obtained from commercial sources.

\section{RESULTS}

\section{The Anammox process using waste water}

Batch experiments. The first attempts to run Anammox on a simple synthetic denitrification (mineral) medium with sulfide and acetate as electron donors failed. Analysis of the influent and effluent of the original denitrification reactor revealed no unusual or unexpected (changes of) inorganic components. To obtain more information about specific requirements for Anammox, batch experiments were carried out with waste water supplemented with various chemicals (Table 1). The addition of 5 or $50 \mathrm{mM}$

Table 1. Effect of additions of various compounds on the Anammox activity in batch experiments with waste water or in continuous experiments with an FBR

\begin{tabular}{|c|c|c|}
\hline Compound & Concentration & $\begin{array}{c}\text { Effect on Anammox } \\
\text { activity }\end{array}$ \\
\hline \multicolumn{3}{|l|}{ Batch expts } \\
\hline Acetate & 1 or $5 \mathrm{mM}$ & Increase, nitrite formation \\
\hline Propionate & $1 \mathrm{mM}$ & No effect \\
\hline Glucose & $1 \mathrm{mM}$ & Increase, nitrite formation \\
\hline Fructose & $1 \mathrm{mM}$ & Increase, nitrite formation \\
\hline Lactate & $1 \mathrm{mM}$ & No effect \\
\hline Casamino acids & $50 \mathrm{mg} \mathrm{l}^{-1}$ & No effect \\
\hline Sulfide & 1 or $5 \mathrm{mM}$ & Increase \\
\hline Sulfur & 1 or $5 \mathrm{mM}$ & Increase, nitrite formation \\
\hline Sulfite & $1 \mathrm{mM}$ & Increase \\
\hline Thiosulfate & $1 \mathrm{mM}$ & Increase, nitrite formation \\
\hline $\mathrm{KCl}$ & $50 \mathrm{mM}$ & No effect \\
\hline $\mathrm{KHCO}_{3}$ & 20 or $40 \mathrm{mM}$ & No effect \\
\hline EDTA & $100 \mathrm{mg} \mathrm{l}^{-1}$ & No effect \\
\hline $\mathrm{KH}_{2} \mathrm{PO}_{4}$ & 5 or $50 \mathrm{mM}$ & Loss of activity \\
\hline $\mathrm{KH}_{2} \mathrm{PO}_{4}$ & $1 \mathrm{mM}$ & No effect \\
\hline \multicolumn{3}{|c|}{ Continuous expts } \\
\hline Acetate & $2 \mathrm{mM}$ & $-28 \%$ \\
\hline Glucose & $1 \mathrm{mM}$ & $-12 \%$ \\
\hline Pyruvate & $1 \mathrm{mM}$ & $-20 \%$ \\
\hline Formate & $5 \mathrm{mM}$ & $-10 \%$ \\
\hline Cysteine & $0.8 \mathrm{mM}$ & $-11 \%$ \\
\hline Sulfide & $2 \mathrm{mM}$ & $+20 \% *$ \\
\hline Sulfide & $2 \mathrm{mM}$ & $+60 \% \dagger$ \\
\hline Thiosulfate & $2 \mathrm{mM}$ & $+47 \%$ \\
\hline Hydroxylamine & $2 \mathrm{mM}$ & $-28 \%$ \\
\hline $\mathrm{N}_{2} \mathrm{O}$ & $0.7 \mathrm{mM}$ & No effect \\
\hline Nitrite & 2,4 or $6 \mathrm{mM}$ & $+11,24$, or $54 \%$ \\
\hline
\end{tabular}

* Nitrite formation during a pulse feed.

† Addition during intermittent feeding of the reactor. 


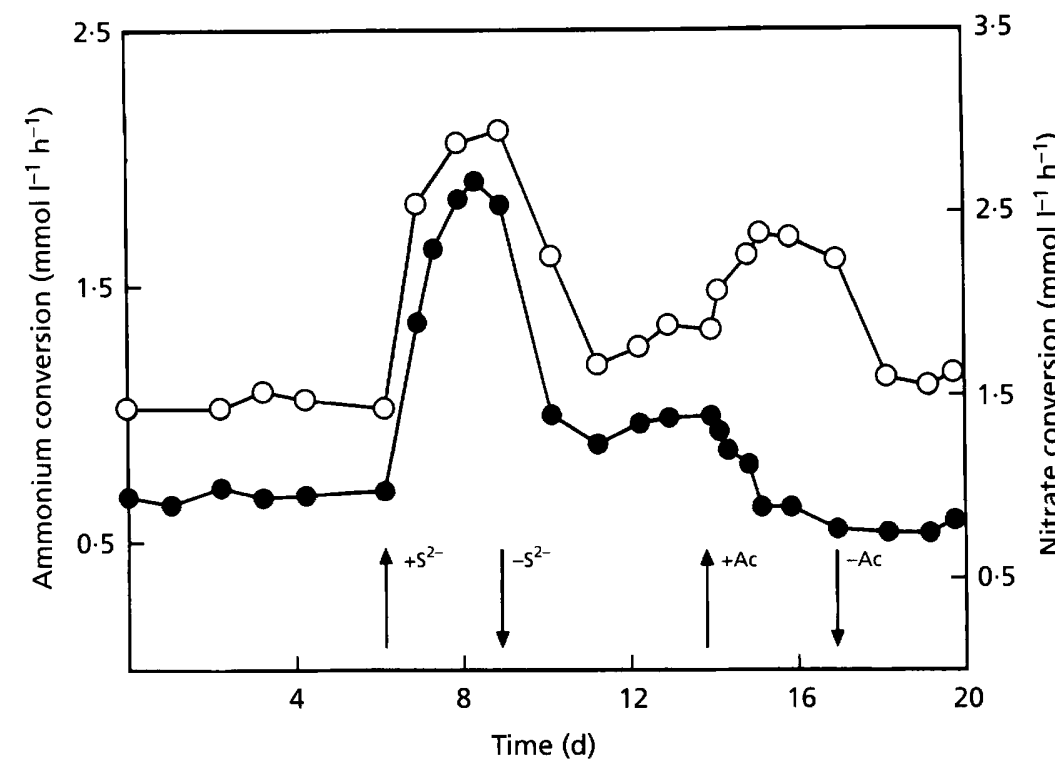

Fig. 1. Effect of sulfide and acetate pulses on the Anammox activity in an FBR intermittently fed with waste water. $\mathrm{S}^{2-}$, pulse of $2 \mathrm{mM}$ sulfide; $A C_{\text {, }}$ pulse of $2 \mathrm{mM}$ acetate. $\mathrm{NH}_{4}^{+} ; \mathrm{O}, \mathrm{NO}_{3}^{-}$.

phosphate, commonly used as a $\mathrm{pH}$ buffer in batch experiments, caused complete loss of the ability to oxidize ammonium anaerobically, but $1 \mathrm{mM}$ phosphate was tolerated. Addition of $50 \mathrm{mM} \mathrm{KCl}$ or $40 \mathrm{mM} \mathrm{KHCO}_{3}$ had no effect. Phosphate was thus the cause of inhibition. Electron donors, both organic and inorganic increased the ammonium oxidation rate. However, in almost all cases, this positive effect was accompanied by transient nitrite formation. At the end of a typical batch experiment, nitrite became detectable at the moment that all ammonium was used. When excess nitrate $(5 \mathrm{mM})$ was present, the addition of nitrite accelerated the ammonium oxidation rate.

Continuous experiments. In batch experiments carried out with a large amount of biomass, the precise influence of added components on the growth of anaerobic ammonium oxidizers could not be measured. These experiments only provided insight into the inhibitory or stimulatory potential of certain components. Continuous runs and a few intermittent feeding experiments were carried out to investigate the effect of adding electron donors and electron acceptors on the Anammox activity. Organic electron donors (Table 1) decreased Anammox activity in all cases, while inorganic sulfur-based electron donors such as thiosulfate and sulfide had a positive effect. Fig. 1 shows the changes in the ammonium and nitrate conversion rates in the reactor during a sulfide or acetate pulse. Adding trace elements had no effect, indicating that no trace elements were missing in the original waste water. The provision of nitrite as an extra electron acceptor increased the ammonium conversion. This indicated that nitrite was necessary for Anammox activity, and that the stimulation of the additional sulfur sources might be due to nitrite formation from nitrate. During intermittent medium supply, the effect of increasing the inlet sulfide concentration was even more pronounced. This could imply that pulse-like sulfide additions caused more nitrite formation per molecule supplied. By in- creasing the nitrite concentration to $6 \mathrm{mM}$, an almost complete conversion of ammonium $(6 \mathrm{mM})$ could be accomplished. Light had a negative effect $(30-50 \%)$ on the ammonium removal rate. During all following experiments the equipment was always covered with black plastic and paper to eliminate this effect.

\section{The Anammox process on synthetic medium}

Start-up and operation with 'autotrophic' synthetic medium. It was possible to start-up and maintain an Anammox fluidized bed culture using an 'autotrophic' mineral medium with ammonium, nitrite and carbonate (see Methods). Inoculation with the original biofilm still attached to the sand particles facilitated the start-up considerably. Characteristic start-up results are shown in Fig. 2. The feed of ammonium was increased stepwise up to $25 \mathrm{mM}$, with a concomitant stepwise increase in nitrite. The highest feed level tested was $35 \mathrm{mM}$ nitrite and $30 \mathrm{mM}$ ammonium. Dinitrogen gas production increased with increasing feed load. A conversion of $3.1 \mathrm{~kg}$ $\mathrm{NH}_{4}^{+} \mathrm{m}^{-3} \mathrm{~d}^{-1}$ was achieved with a feed of $30 \mathrm{mM} \mathrm{NH} \mathrm{m}_{4}^{+}$. A total of 15 runs have been carried out with synthetic medium, the longest lasting over 7 months. During the runs the colour of the culture changed slowly from brown to red. Two to three months were required to obtain completely red biolayers and formation of new biofilm on the sand.

General observations. When cysteine (to reduce the redox potential) or pyruvate [to supply electron donor (Abeliovich \& Vonshak, 1992)] were added to the medium, a steady reduction of the Anammox activity (20\% activity loss per $6 \mathrm{~d}$; feed $5 \mathrm{mM} \mathrm{NH} \mathrm{mH}_{4}^{+}$) was observed. If a large excess of nitrite $(8 \mathrm{mM})$ and ammonium $(8 \mathrm{mM})$ was suddenly supplied, all activity was lost. However, the Anammox activity could be recovered by flushing the column with anoxic tap water until nitrite concentrations decreased below $10 \mathrm{mg} \mathrm{l}^{-1}$, resulting in a steep 


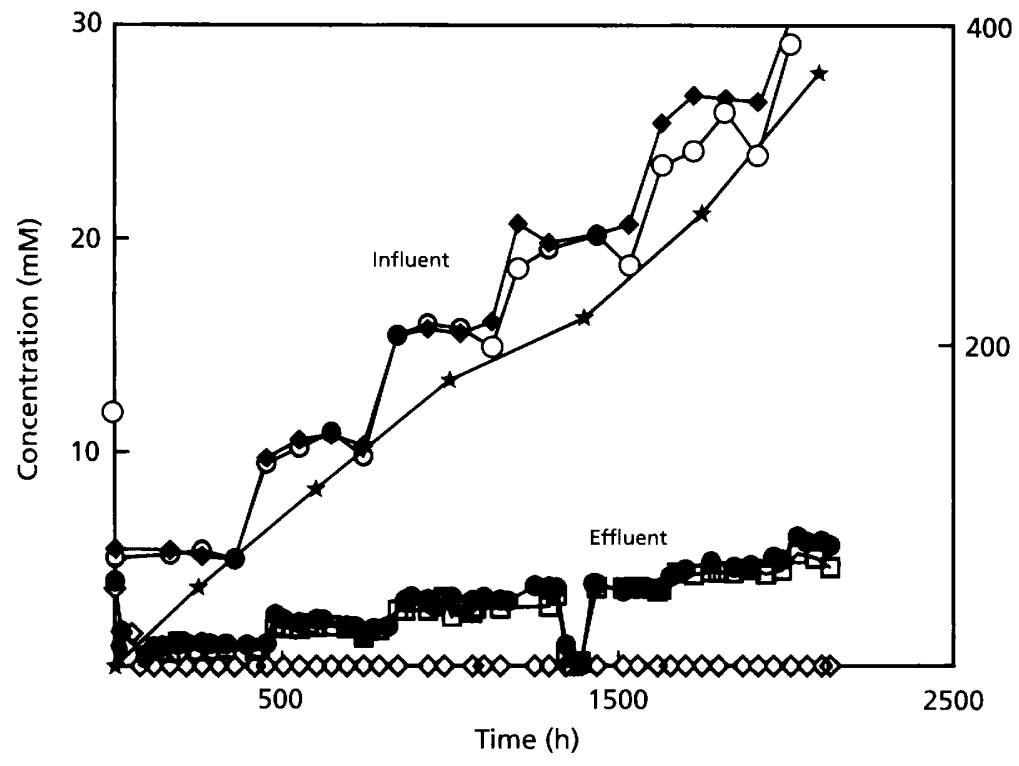

Fig. 2. Start-up and continuous operation of the FBR on synthetic medium, and gas production during increase of the ammonium and nitrite load. Influent: $O$, $\mathrm{NH}_{4}^{+} ; \diamond, \mathrm{NO}_{2}^{-}$. Effluent: $\bullet, \mathrm{NH}_{4}^{+} ; \square, \mathrm{NO}_{3}^{-} ; \diamond$, $\mathrm{NO}_{2}^{-} ; \star$, gas production.

$(-350 \mathrm{mV})$ decline in the redox potential. When the feed was restarted (sometimes at a lower feed load), gas bubbles appeared within $1 \mathrm{~h}$ and the nitrite and ammonium levels fell. During the first runs a calcium concentration of $6 \mathrm{mg} \mathrm{l}^{-1}$ was used. This concentration was increased to $50 \mathrm{mg} \mathrm{l}^{-1}$ since it was shown by Austerman-Haun et al. (1993) to improve biofilm formation. Visible growth of red biomass on the sand particles was then observed.

Nitrogen balance. Instead of the expected 1:1 removal of ammonium and nitrite predicted from the equation of Broda (1977), a 1·3:1 ratio for the $\mathrm{NO}_{2}^{-}: \mathrm{NH}_{4}^{+}$removal was found. This appeared to be due to the formation of nitrate. During the first experiments on synthetic medium, $2 \mathrm{mM}$ nitrate had been added to the feed in order to keep the redox potential at approximately $150 \mathrm{mV}$. This was also the case when waste water with excess nitrate was used. Once it was discovered that nitrate was formed during the Anammox process, it was omitted from the feed. Nitrate production accounted for $10 \%$ of the total nitrogen feed. From four independent runs, 31 nitrogen balances were made. This gave a ratio of $\mathrm{NH}_{4}^{+}$-conversion: $\mathrm{NO}_{2}^{-}$-conversion: $\mathrm{NO}_{3}^{-}$-production of $1: 1 \cdot 31$ $\pm 0 \cdot 06: 0 \cdot 22 \pm 0 \cdot 02$. Hydroxylamine, an intermediate of aerobic ammonium oxidation, was not detected in the effluent, and $\mathrm{N}_{2} \mathrm{O}$ was not detected in the gas produced. However, if the system was disturbed (e.g. by failure of $\mathrm{pH}$ regulation), $\mathrm{N}_{2} \mathrm{O}$ was formed in small amounts $(0 \cdot 3 \%$ of total gas production).

Specific Anammox activity. The specific Anammox activity of the biomass in the FBR being fed with $25 \mathrm{mM}$ ammonium and nitrite was 700-800 nmol $\mathrm{NH}_{4}^{+} \mathrm{h}^{-1}(\mathrm{mg}$ VS $)^{-1}$. The feeding rate of this reactor could be doubled instantaneously without causing problems, implying that the maximum specific activity of the biomass in the reactor was $1300-1500 \mathrm{nmol} \mathrm{NH}_{4}^{+} \mathrm{h}^{-1}(\mathrm{mg} \mathrm{VS})^{-1}$. However, when fresh samples from this reactor were tested for their Anammox activity in batch culture, the activity was

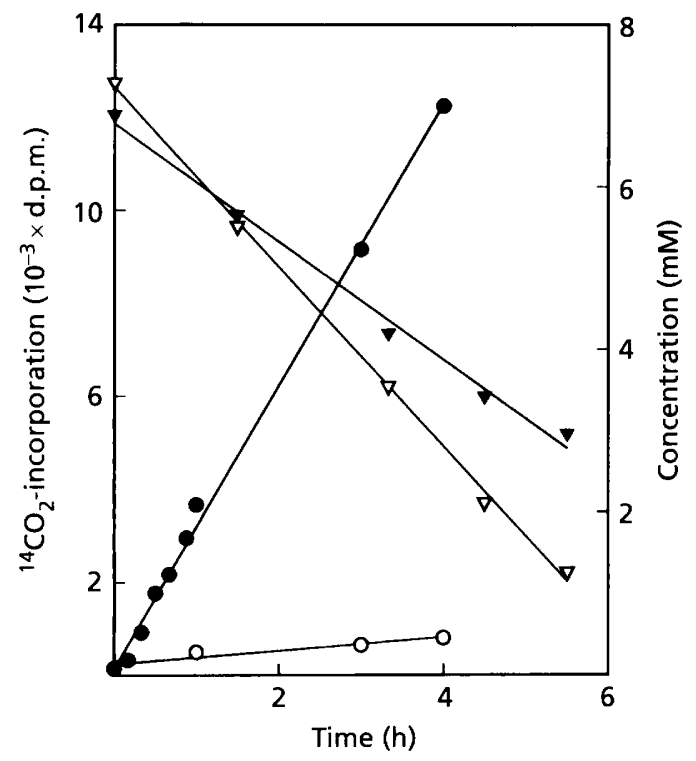

Fig. 3. Incorporation of ${ }^{14} \mathrm{CO}_{2}$ in a sample of an enrichment culture of Anammox micro-organisms during oxidation of ammonium with nitrite. 0 , d.p.m. ${ }^{14} \mathrm{CO}_{2}$ incorporated when incubated with $\mathrm{NH}_{4}^{+}$and $\mathrm{NO}_{2}^{-} ; 0$, d.p.m. ${ }^{4} \mathrm{CO}_{2}$ incorporated in controls with neither $\mathrm{NH}_{4}^{+}$nor $\mathrm{NO}_{2}^{-} ; \boldsymbol{\nabla}, \mathrm{NH}_{4}^{+}$concentration and $\nabla, \mathrm{NO}_{2}^{-}$concentration in control incubations without labelled $\mathrm{CO}_{2}$.

only half this level [i.e. $300-400 \mathrm{nmol} \mathrm{NH}_{4}^{+} \mathrm{h}^{-1}$ (mg VS $\left.)^{-1}\right]$. This was most probably due to inhibition by the higher nitrite or ammonium concentrations initially present in the batch experiments.

\section{Autotrophic growth of anaerobic ammonium- oxidizers}

$\mathrm{CO}_{2}$-fixation. $\mathrm{CO}_{2}$-fixation was dependent on Anammox activity as shown in Fig. 3. There was no incorporation of ${ }^{14} \mathrm{CO}_{2}$ in the control experiments without $\mathrm{NH}_{4}^{+}$or $\mathrm{NO}_{2}^{-}$. 


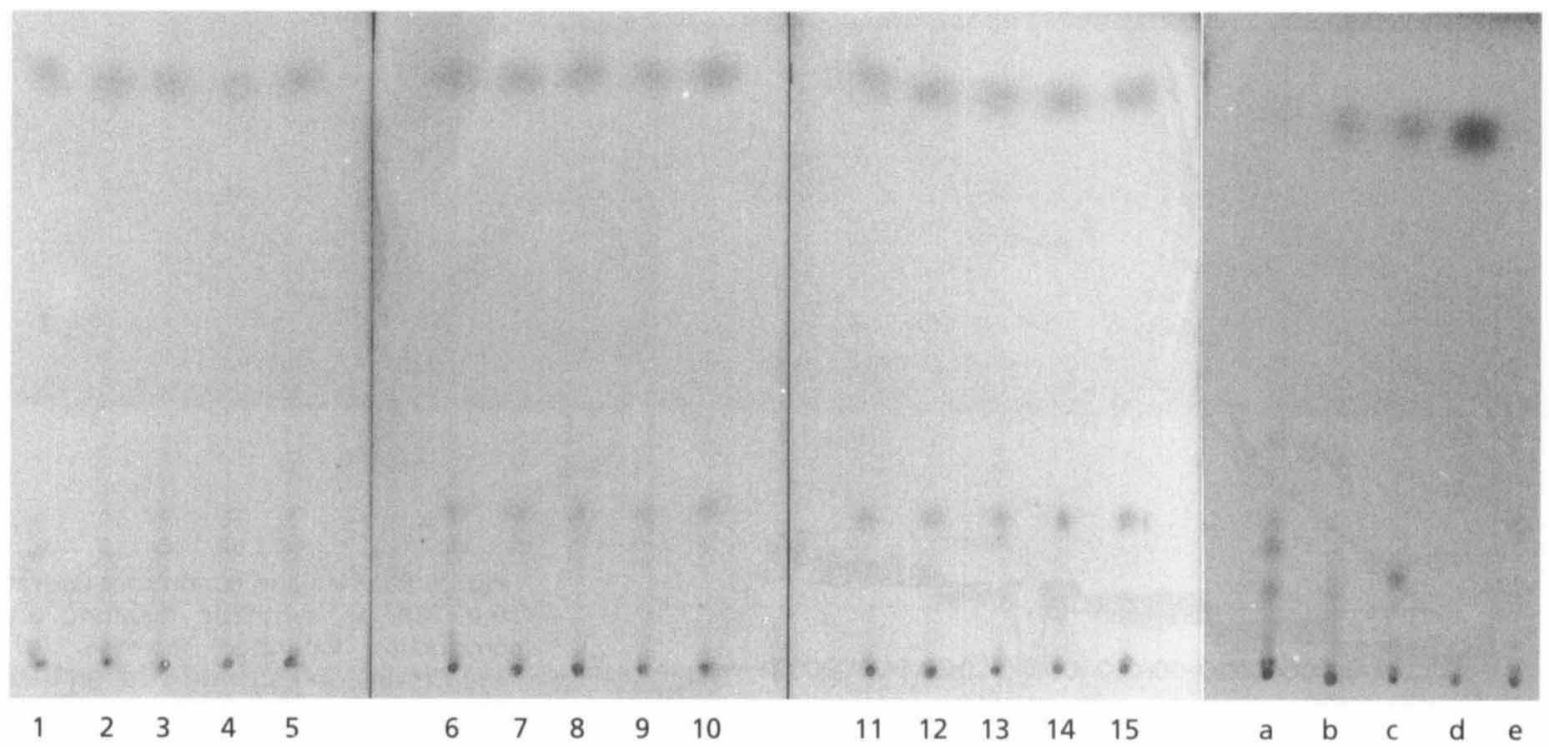

Fig. 4. Increase in the ether lipid content of whole-cell methanolysates during the enrichment for Anammox microorganisms compared with other cultures. Time after start of enrichment: lane 1, $0 \mathrm{~d}$; lane 2, $0 \mathrm{~d}$; lane 3, $6 \mathrm{~d}$; lane 4, $14 \mathrm{~d}$; lane 5, $22 \mathrm{~d}$; lane 6, $31 \mathrm{~d}$; lane 7, $40 \mathrm{~d}$; lane 8, $48 \mathrm{~d}$; lane 9, $54 \mathrm{~d}$; lane 10, $61 \mathrm{~d}$; lane 11, $69 \mathrm{~d}$; lane 12, $76 \mathrm{~d}$; lane 13, $90 \mathrm{~d}$; lane 14, $181 \mathrm{~d}$; lane 15, $198 \mathrm{~d}$. Lane a, methanogenic sludge; lane b, pilot plant Anammox sludge; lane $c$, Anammox enrichment culture; lane d, Nitrosomonas europaea; lane e, Methanothrix soehngenii.

The $\mathrm{CO}_{2}$ incorporation rate was $12.5 \mathrm{nmol} \mathrm{Ch}^{-1}$ (mg $\mathrm{VS})^{-1}$ and the $\mathrm{NH}_{4}^{+}$conversion rate was $307 \mathrm{nmol}$ $\mathrm{NH}_{4}^{+} \mathrm{h}^{-1}$ (mg VS) ${ }^{-1}$. Hence, the biomass yield of Anammox was $0.041 \mathrm{~mol} \mathrm{C}$ incorporated per mol $\mathrm{NH}_{4}^{+}$ oxidized. Conversion of $20 \mathrm{mmol} \mathrm{NH}_{4}^{+}$will give a biomass formation of $20 \mathrm{mg}$ dry weight (assuming a biomass carbon content of $50 \%$ ).

Other biomass measurements. When the biomass in the FBR had reached the level of the overflow, a kind of pseudo-steady situation was obtained. The amount of biomass which left the reactor at this time was therefore a measure of the biomass production. During a period of $16 \mathrm{~d}$, the dry weight of the settled and suspended material was estimated to be $18-34 \mathrm{mg}$ VS $(1 \text { feed })^{-1}$. This is of the same order as the $20 \mathrm{mg}$ calculated from the $\mathrm{CO}_{2}$ fixation.

RuBPCase. Since $\mathrm{HCO}_{3}^{-}$was the only carbon source provided, the Anammox micro-organisms are presumably autotrophs. Measurements to demonstrate an increase of the activity of RuBPCase, the key enzyme of the Calvin cycle, between the original sludge and the enrichment were done. Although the cell-free extract of the original sludge grown on waste water possessed a low RuBPCasedependent $\mathrm{CO}_{2}$-fixation activity of $1.02 \mathrm{nmol} \mathrm{min}^{-1}(\mathrm{mg}$ protein $)^{-1}$, the cell-free extract of the enrichment had an

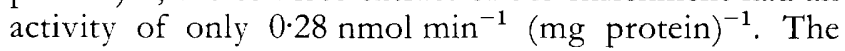
activity of the enrichment was just above the detection limit (i.e. only twofold higher than the control). However, for the (extremely slow) growth of the Anammox sludge,

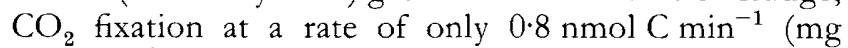
protein $)^{-1}$ would be required. Sulfide, one of the major electron donors for the original sludge (Mulder et al., 1995), might explain the presence of some autotrophic metabolism in the original sample. Additional tests were done to examine whether some components in the cellfree extract had an inhibitory effect on the enzyme activity. Mixing on a $1: 1$ basis with cell-free extract of Nitrosomonas europaea gave the expected dilution of activity from $12 \cdot 1$ to $6.15 \mathrm{nmol} \min ^{-1}$ (mg protein) $)^{-1}$.

\section{Effect of dioxygen}

The amount of $\mathrm{O}_{2}$ leaking through the tubing and connections of the fluidized bed system was measured with a Clark-type oxygen electrode in a separate reactor without biomass. The reactor was made anaerobic by flushing with dinitrogen gas through the bottom and an argon flush through the head space of the column for $30 \mathrm{~min}$. Argon was continuously used in the reactor during operation, but was discontinued for the measurement of potential oxygen leakage. The initial rate of oxygen leakage was $20 \mu \mathrm{mol} \mathrm{O}_{2} \mathrm{~h}^{-1}$. When the argon flush was maintained during the measurements, oxygen leakage was not detected. Even in the worst-case situation, the amount of oxygen would only be enough to oxidize $0.2 \%$ of the total amount of $12 \mathrm{mM}$ ammonium and $15 \mathrm{mM}$ nitrite converted per $\mathrm{h}$.

In a few batch experiments, oxygen was deliberately introduced by shaking cultures with an aerobic head space. This caused complete inhibition of the anaerobic ammonium conversion (Jetten et al., 1995). In static cultures exposed to air (through a cotton plug), the anaerobic ammonium oxidation and nitrite reduction started after a delay, presumably after facultative anaerobic bacteria removed the oxygen dissolved in the medium and a $\mathrm{O}_{2}$-gradient had been established, thus providing an anaerobic environment at the bottom of the flasks (Kato et al., 1993). 


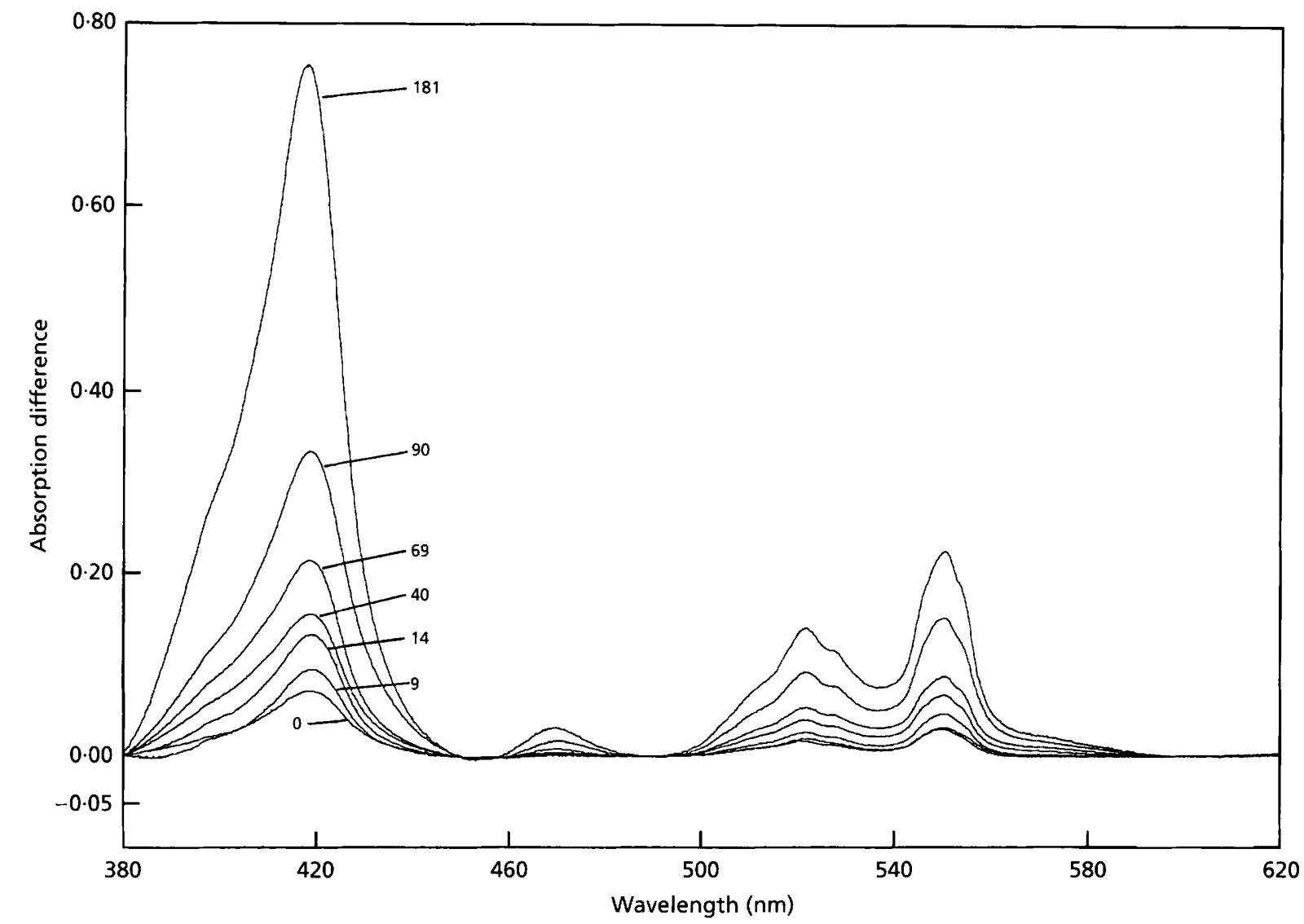

Fig. 5. Increase in the cytochrome content during enrichment for Anammox micro-organisms. Cytochrome spectra were measured at $77 \mathrm{~K}$. The cells were reduced by dithionite in an argon atmosphere. The measured spectra were all normalized to $1 \mathrm{mg}$ protein $\mathrm{ml}^{-1}$. The numbers on the curves represent days after the start-up. Note typical peak at $470 \mathrm{~nm}$.

\section{Aerobic nitrifiers}

The standard, aerobic MPN method showed that aerobic nitrifiers were present in the sludge at all times. During the enrichment for Anammox bacteria on synthetic medium, the number of nitrifiers present in the culture did not increase : ammonium oxidizers stayed at about $9 \pm 5 \times$ $10^{3}$ cells (mg VS) $)^{-1}$ and nitrite oxidizers at $1 \cdot 0 \pm 0 \cdot 9 \times 10^{3}$ cells (mg VS) $)^{-1}$.

Electron micrographs of the aerobic MPN cultures showed the characteristic membrane structures of Nitrosomonas europaea, and immunofluorescence microscopy with antibodies against Nitrosomonas europaea gave a positive reaction. Addition of penicillin $G\left(35 \mathrm{mg} \mathrm{l}^{-1}\right)$ completely inhibited growth of the MPN cultures. Attempts to isolate the nitrifiers were unsuccessful, due to persistent contamination by heterotrophs.

\section{Effect of inhibitors on Anammox activity}

The specific inhibitors (hydrazine, acetone, N-serve, allylthiourea) for the first step of aerobic ammonium oxidation did not affect the Anammox activity. However, acetylene inhibited the Anammox process by $87 \%$ compared with the control. Penicillin G, penicillin $V$ and specific inhibitors or stimulators for methanogens (bromoethane sulfonic acid) and sulfate-reducers $\left(\mathrm{NaMoO}{ }_{4} / \mathrm{Na}_{2} \mathrm{SO}_{4}\right)$ had no effect. Chloramphenicol, which can have a direct inhibitory effect on denitrification enzymes, did not inhibit the initial rate of Anammox activity.

\section{TLC of ester and ether lipids}

The level of ether lipids increased during the enrichment for Anammox micro-organisms (Fig. 4). Control experiments with methanogenic sludge, Nitrosomonas europaea, and Methanothrix soebngenii served as reference. The ester lipids typical for (eu)bacterial membranes remained present during the enrichment.

\section{Cytochrome spectra}

During the enrichment of anaerobic ammonium oxidizers on synthetic medium, the colour of the biomass changed from brownish to red. Spectra taken from whole cells showed a clear increase in typical haem spectra, in particular of the cytochrome $c(540-554 \mathrm{~nm} ; \alpha$-region, Fig. 5). Measurements at higher wavelengths (700$1100 \mathrm{~nm}$ ) showed that the characteristic maxima of bacteriochlorophyll $a$ and $b$ (Stanier et al., 1986) were 


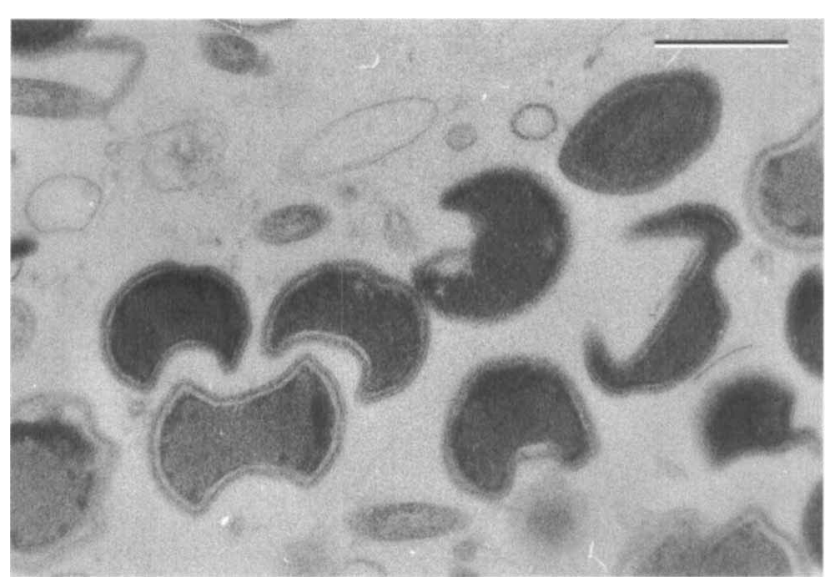

Fig. 6. Electron micrograph of resuspended Anammox biofilm grown on synthetic medium in an FBR. The dominant species in the enrichment culture. Bar, $1 \mu \mathrm{m}$.

absent. The presence of carotenoids of the spheroidene group giving peaks between 450 and $550 \mathrm{~nm}$ was also not evident. The spectra of reduced cell suspensions at $77 \mathrm{~K}$ revealed the absence of cytochromes a (600-605nm; location of terminal oxidase), $b(554-564 \mathrm{~nm})$ and $d_{1}$ (662-665 $\mathrm{nm} ; c d_{1}$-containing nitrite reductase). Spectra recorded in the presence of $\mathrm{CO}$ showed that the $\mathrm{CO}$ gas was binding to cytochromes $c$. No oxidases of $b$-type cytochromes were observed. Interestingly, during the increase in Anammox activity, a peak at $470 \mathrm{~nm}$ gradually increased in intensity. This spectroscopic feature reacted irreversibly with $\mathrm{CO}$, as indicated by a shift from 470 to $450 \mathrm{~nm}$.

\section{Morphology}

The dominant micro-organism of the enrichment culture was Gram-negative, with an unusual and irregular morphology as shown in Fig. 6. The cells were usually seen as single cells or in pairs, the latter possibly being a division state. When the biofilm was disrupted and the cells were allowed to settle for two or more days in a centrifuge tube, the clear appearance of the red colour was even more pronounced. The organisms from this sediment could easily be collected with a Pasteur pipette. Electron micrographs of this fraction showed an almost pure culture of the already dominant type of cells.

To gain an indication of the numbers of the apparently dominant type in the enrichment culture, a large series of electron micrographs were taken from different sections of imbedded samples. After $177 \mathrm{~d}$ enrichment, $64 \%$ of all cells counted (total count $=11433$ ) were of the described dominant type (Fig. 6). This is a fourfold increase in numbers compared with the inoculum used for the startup of the process $(16 \%$; total count $=10200)$. The dominant organisms appear to occupy a much larger volume than the other organisms present in the material. In some parts of the biolayers of the enrichment cultures, a few autofluorescent cells reminiscent of methanogens were observed.

\section{DISCUSSION}

The continuous experiments with the systematic, stepwise addition of various supplements to the waste water showed that nitrite was the main electron acceptor used in Anammox, as was observed before by van de Graaf $e t$ al. (1995). It is likely that all other positive effects can be interpreted to the effect that they transiently stimulated (additional) nitrite production. The negative effect of prolonged addition of organic compounds, such as cysteine or pyruvate, may be due to the undesirable increase of a heterotrophic population overgrowing the organisms responsible for the Anammox process. Such a phenomenon is well known for overgrowth of aerobic nitrifiers by heterotrophs in the presence of organic materials (Tijhuis et al., 1994).

The biomass responsible for the Anammox process can now be reproducibly grown autotrophically in an inorganic (synthetic) medium, with bicarbonate as the only carbon source. Considering the low growth rate $\left(0 \cdot 001 \mathrm{~h}^{-1}\right)$, it is not surprising that a biomass retention system, such as an FBR with biofilm attached to solid support, is required. Indeed, enrichment cultures in suspended continuous cultures, even at a dilution rate as low as $0.01 \mathrm{~h}^{-1}$ failed, and complete conversion of ammonium only occurred in this system when sufficient biomass had accumulated on the fermenter walls.

It has been shown that nitrite, an intermediate in nitrate reduction, can accumulate in waste-water-treatment systems during changes in the reactor loading (Gommers et al., 1988). It is therefore logical to suggest that the Anammox process with nitrate as electron acceptor could be the overall reaction of at least two types of bacteria, one of which reduces nitrate to nitrite using sulfide or degradable organic material as an electron donor. The second species would be the one that oxidizes ammonium with nitrite as the electron acceptor. Due to the direct supply of nitrite, the nitrite-providing nitrate-reducing organism would no longer be necessary in the Anammox enrichment culture using synthetic medium. The observed difference between the inhibitory effect of chloramphenicol on the original sludge (van de Graaf et al., 1995) and the non-inhibitory effect of chloramphenicol on the enrichment culture could be explained by assuming that the nitrite-producing reaction was the one sensitive to chloramphenicol. Given the extremely low growth rate of the new enrichment, a short-term ( $24 \mathrm{~h}$ ) effect of chloramphenicol (i.e. inhibition of protein synthesis) is unlikely.

The role of nitrate formation is not yet clear. The most likely explanation is that reducing power is required for $\mathrm{CO}_{2}$-fixation. When the general formula ' $\mathrm{CH}_{2} \mathrm{O}$ ' for biomass is used, the production of $0.22 \mathrm{~mol} \mathrm{NO}_{3}^{-}$from $\mathrm{NO}_{2}^{-}$would allow the fixation of $0.0425 \mathrm{CO}_{2}$ according to the reaction:

$$
\begin{aligned}
& 1 \mathrm{NH}_{4}^{+}+1 \cdot 31 \mathrm{NO}_{2}^{-}+0.0425 \mathrm{CO}_{2} \rightarrow \\
& 1.045 \mathrm{~N}_{2}+0.22 \mathrm{NO}_{3}^{-}+1.87 \mathrm{H}_{2} \mathrm{O}+0.09 \mathrm{OH}^{-} \\
& \quad+0.0425 \mathrm{CH}_{2} \mathrm{O}
\end{aligned}
$$

The anaerobic conversion of $20 \mathrm{mM}$ ammonium (with $0.22 \mathrm{~mol} \mathrm{NO}_{3}^{-}$as a by-product) would thus allow the production of $26 \mathrm{mg}$ dry weight. This is close to the 
observed $20 \mathrm{mg}$ biomass produced. This is of the same order of magnitude as aerobic ammonium-oxidizing bacteria such as Nitrosomonas europaea, which produce $25 \mathrm{mg}$ dry weight from the same amount of ammonium (de Bruijn et al., 1995). The possibility that nitrate would be formed by oxidation of $\mathrm{NO}_{2}^{-}$to $\mathrm{NO}_{3}^{-}$by Nitrobacter species is very unlikely in view of the very low quantity of $\mathrm{O}_{2}$ penetrating into the reactor.

The original sludge had an anaerobic ammonium removal rate of $0.4 \mathrm{~kg} \mathrm{~N} \mathrm{~m}^{-3} \mathrm{~d}^{-1}$ (Mulder et al., 1995). After enrichment with synthetic medium, the ammonium removal rate was $3 \mathrm{~kg} \mathrm{NH}_{4}^{+} \mathrm{m}^{-3} \mathrm{~d}^{-1}$ (equivalent to $2.4 \mathrm{~kg} \mathrm{~N} \mathrm{~m}^{-3} \mathrm{~d}^{-1}$ ). The total nitrogen removal of the Anammox reactor, including the conversion of nitrite, was $4.8 \mathrm{~kg} \mathrm{~N} \mathrm{~m}^{-3} \mathrm{~d}^{-1}$. In aerobic, nitrifying FBRs, ammonium conversion rates of $1.8-2.9 \mathrm{~kg} \mathrm{~N} \mathrm{~m}^{-3} \mathrm{~d}^{-1}$ have been obtained, depending on the pre-treatment system (Mulder et al., 1986). Higher nitrification rates of $5 \mathrm{~kg} \mathrm{~N} \mathrm{~m}^{-3} \mathrm{~d}^{-1}$ were recently reached with a biofilm airlift suspension reactor (Tijhuis et al., 1994). Compared with these aerobic systems, the Anammox process can contribute significantly to the nitrogen removal from waste water with low carbon content.

The consistent presence of the nitrifiers in the Anammox sludge suggests that they can survive long periods of anaerobiosis, as shown by Abeliovich (1987). Poth (1986) showed that a new isolate, identified as a Nitrosomonas species, was able to produce $\mathrm{N}_{2}$ under anaerobic conditions. More recently, it has been shown that Nitrosomonas europaea, under strictly anaerobic conditions, utilized nitrite as electron acceptor, and pyruvate as energy source (Abeliovich \& Vonshak, 1992), and pure and mixed cultures of Nitrosomonas eutropha were able to denitrify with hydrogen and ammonium as electron donor (Bock et al., 1995). If the consistent but low numbers of nitrifiers $\left[10^{3}-10^{4}(\mathrm{mg} \mathrm{VS})^{-1}\right]$ present are compared with the value of $9 \times 10^{9}$ cells $(\mathrm{mg} \mathrm{dry} \mathrm{wt})^{-1}$ (biomass of $35 \mathrm{mg}$ dry wt $\mathrm{l}^{-1}$ and $3 \times 10^{8} \mathrm{cells} \mathrm{m}^{-1}$ ) of a pure culture of Nitrosomonas europaea, their contribution to the Anammox is highly unlikely. Even if the nitrification of the aerobic nitrifier was the same under anaerobic conditions as under aerobic conditions, their activity would be three orders of magnitude too low to explain the observed ammonium oxidation rate of $800 \mathrm{nmol} \mathrm{NH}_{4}^{+} \mathrm{h}^{-1}$ (mg VS) ${ }^{-1}$.

The presence of ether lipids seems to be confined to the most ancient micro-organisms (e.g. the Archaea or the deepest phylogenetic branches within the Bacteria), thus suggesting that the ether linkage in the lipids could have appeared during the evolution of life before the ester types. Membrane lipids of the members of the order Thermogotales are based on ester and ether linkage (Gambacorta et al., 1994). Also members of the genus Aquifex were found to possess diethers, but not archaeal diethers. Knowledge of the lipids can be used for taxonomic purposes, once catalogues of signature lipids have been developed (Gambacorta et al., 1994).

The findings reported here show that the observed increase in Anammox capacity of the entichment is directly related to an increase in morphologically conspicuous micro-organisms, an increase in ether lipids and an increase in cytochromes. These properties might all be due to one and the same organism, although the possibility remains that two or more micro-organisms are responsible for the Anammox reaction. In the future, molecular techniques, such as $16 \mathrm{~S}$ RNA analysis, will be used to unravel the consortium structure.

\section{ACKNOWLEDGEMENTS}

This research was supported by the Netherlands Foundation of Applied Research (STW), Gist-brocades and the Royal Netherlands Academy of Arts and Sciences. We thank H. Slijkhuis of Gist-brocades and A. Mulder of TNO-IMW for their stimulating discussions. We thank especially M. Hazelaar for assistance and interpretation of the cytochrome spectra, W. Batenburg-van de Vegte for performing the electron and other microscopical photographs, Brian Jones for advice on the TLC work, and E. Dumoulin and F. van Velzen for their dedicated work on the FBRs.

\section{REFERENCES}

Abeliovich, A. (1987). Nitrifying bacteria in waste water reservoirs. Appl Environ Microbiol 53, 754-760.

Abeliovich, A. (1992). Transformations of ammonia and the environmental impact of nitrifying bacteria. Biodegradation 3, 255-264.

Abeliovich, A. \& Vonshak, A. (1992). Anaerobic metabolism of Nitrosomonas europaea. Arch Microbiol 158, 267-270.

Alexander, M. (1982). Most probable number method for microbial populations. In Methods of Soil Analysis, Part 2, Chemical and Microbiological Properties, pp. 815-820. Edited by C. A. Black. Madison, WI: American Society of Agronomy.

Austermann-Haun, U., Seyfried, C. F., Zellner, G. \& Diekmann, H. (1993). Start-up of anaerobic fixed film reactors: technical aspects. In I AWQ Second International Specialized Conference on Biofilm Reactors, pp. 387-398. Paris: IAWQ.

Beudeker, R. F., Cannon, G. C., Kuenen, J. G. \& Shively, J. M. (1980). Relations between D-ribulose-1,5-bisphosphate carboxylase, carboxysomes and $\mathrm{CO}_{2}$-fixing capacity in the obligate chemolithotroph Thiobacillus neapolitanus grown under energy limitation in the chemostat. Arch Microbiol 124, 185-189.

Bock, E., Schmidt, I., Stuiven, R. \& Zart, D. (1995). Nitrogen loss caused by denitrifying Nitrosomonas cells using ammonium or hydrogen as electron donors and nitrite as electron acceptor. $A r c h$ Microbiol 163, 16-20.

Broda, E. (1977). Two kinds of lithotrophs missing in nature. $Z$ Allg Mikrobiol 17, 491-493.

de Bruijn, P., van de Graaf, A. A., Jetten, M. S. M., Robertson, L. A. \& Kuenen, J. G. (1995). Growth of Nitrosomonas europaea on hydroxylamine. FEMS Microbiol Lett 125, 179-184.

Frear, D. S. \& Burell, R. C. (1955). Spectrophotometric method for determining hydroxylamine reductase activity in higher plants. Anal Chem 27, 1664-1665.

Gambacorta, A., Trincone, A., Nicolaus, B., Lama, L. \& De Rosa, M. (1994). Unique features of lipids of Archaea. Syst Appl Microbiol 16, 518-527.

Gommers, P. J. F., Bijleveld, W., Zuijderwijk, F. J. W. \& Kuenen J. G. (1988). Simultaneous sulfide and acetate oxidation in a denitrifying fluidized bed reactor. Water Res 20, 1085-1092. 
van de Graaf, A. A., Mulder, A., de Bruijn, P., Jetten, M. S. M., Robertson, L. A. \& Kuenen, J. G. (1995). Anaerobic oxidation of ammonium is a biologically mediated process. Appl Environ Microbiol 61, 1246-1251.

Herbert, D., Phipps, P. J. \& Strange, R. E. (1971). Chemical analysis of microbial cells. Methods Microbiol 5, 131-145.

Jetten, M. S. M., Logemann, S., Muyzer, G., de Vries, S., van Loosdrecht, M. C. M., Robertson, L. A. \& Kuenen, J. G. (1995). Novel principles and processes in the removal of nitrogen from waste water. In Proceedings of the Beijerinck Centennial, pp. 126-127. Edited by W. A. Scheffers \& J. P. van Dijken. Delft, The Netherlands: Delft University Press.

Kato, M. T., Field, J. A. \& Lettinga, E. (1993). High tolerance of methanogens in granular sludge to oxygen. Biotechnol Bioeng 42, 1360-1366.

Koops, H. P. \& Moller, U. C. (1992). The lithotrophic ammoniaoxidizing bacteria. In The Prokaryotes, vol. 3, pp. 2625-26372. Edited by A. Balows, H. G. Trüper, M. Dworkin, W. Harder \& K.-H. Schleifer. Berlin: Springer-Verlag.

Kuenen, J. G. \& Robertson, L. A. (1994). Combined nitrificationdenitrification processes. FEMS Microbiol Rev 15, 109-117.

Mulder, A., Heijnen, J. J. \& Hols, H. (1986). Post-treatment of anaerobic sulphide and ammonia containing effluents from methane fermentations in high-rate fluidized bed reactors on laboratory and pilot-plant scale. In Proceedings of the NVA-EWPCA Conference, pp. 413-422. Amsterdam: Elsevier Scientific Publishers.

Mulder, A., van de Graaf, A. A., Robertson, L. A. \& Kuenen, J. G. (1995). Anaerobic ammonium oxidation discovered in a denitrifying fluidized bed reactor. FEMS Microbiol Ecol 16, 177--184.
Poth, M. (1986). Dinitrogen production from nitrite by a Nitrosomonas isolate. Appl Environ Microbiol 52, 957-959.

Ross, H. N. M., Collins, M. D., Tindall, B. J. \& Grant, W. D. (1981). A rapid procedure for the detection of archaebacterial lipids in halophilic bacteria. J Gen Microbiol 123, 75-80.

Schmidt, E. L. \& Belser, L. W. (1982). Nitrifying bacteria. In Methods of Soil Analysis, Part 2, Chemical and Microbiological Properties, pp. 1027-1041. Edited by C. A. Black. Madison, WI: American Society of Agronomy.

Stanier, R. Y., Ingraham, J. L., Wheelis, M. L. \& Painter, P. R. (1986). The photosynthetic eubacteria. In The Microbial World, pp. 344-354. New Jersey: Prentice-Hall Englewood Cliffs.

Tijhuis, L., Rekswinkel, H. G., Loosdrecht, M. C. M. \& Heijnen, J. J. (1994). Dynamics of population and biofilm structure in the biofilm airlift suspension reactor for carbon and nitrogen removal. Water Sci Technol 29, 377-384.

van Wielink, J. E., Oltmann, L. F., Leeuwerik, F. J., de Hollander, J. A. \& Stouthamer, A. H. (1982). A method for in situ characterization of $b$ - and $c$-type cytochromes in Escherichia coli and in Complex III from beaf heart mitochondria by combined spectrum deconvolution and potentiometric analyses. Biochem Biopbys Acta 681, 177-190.

Zumft, W. G. (1992). The denitrifying prokaryotes. In The Prokaryotes, pp. 554-582. Edited by A. Balows, H. G. Trüper, M. Dworkin, W. Harder \& K.-H. Schleifer. Berlin: Springer-Verlag.

Received 5 January 1996; revised 11 March 1996; accepted 15 March 1996. 